\title{
ANALISIS INDEKS KEPUASAN MAYARAKAT (IKM) DAN KUALITAS PELAYANAN PUBLIK (STUDI PADA PDAM BANDARMASIH DI BANJARMASIN)
}

\author{
Fadma Yulianti \\ Sekolah Tinggi Ilmu Ekonomi Indonesia (STIE Indonesia) Banjarmasin \\ Email : fadma@stiei-kayutangi-bjm.ac.id \\ Rofiqah Wahdah \\ Sekolah Tinggi Ilmu Ekonomi Indonesia (STIE Indonesia) Banjarmasin \\ Email : fiqah@stiei-kayutangi-bjm.ac.id
}

\begin{abstract}
ABSTRAK
Penelitian ini bertujuan untuk menganalisis indeks kepuasan masyarakat pada PDAM Bandarmasih di Banjarmasin, dan untuk indikator-indikator kualitas pelayanan Publik pada PDAM Bandarmasih di Banjarmasin. Metode penelitian yang digunakan adalah deskriptif kuanlitatif, dengan menggunakan jenis data kuantitatif. Populasi dalam penelitian ini adalah keseluruhan individu/masyarakat yang mendapatkan pelayanan pada loket pengaduan gangguan pada PDAM Bandarmasih di Banjarmasin. Metode pengambilan sampel yang digunakan adalah sampel insidensial sebanyak 150 orang. Data dianalisis menggunakan Indeks Kepuasan Masyarakat (IKM) berdasarkan Keputusan Men. PAN Nomor: KEP/25/M.PAN/2/2004, dan Important Performance Analysis (IPA). Hasil penelitian menunjukkan bahwa tingkat Kepuasan Masyarakat PDAM Bandarmasih di Banjarmasin berdasarkan tingkat kinerja dan kepentingan masyarakat memiliki kinerja pelayanan yang baik (kategori B). Tingkat rata-rata kesesuaian antara tingkat kinerja dan tingkat kepentingan yang diperoleh dari hasil penelitian sebesar 88,07 mendekati $100 \%$ sehingga dapat disimpulkan secara keseluruhan bahwa pelaksanaan kinerja dengan tingkat kepentingan masuk dalam kategori "sesuai", artinya harapan masyarakat penerima layanan sudah terpenuhi dengan baik.Pemetaaan indikator-indikator kualitas pelayanan Publik pada PDAM Bandarmasih di Banjarmasin dilakukan dengan importancePerformance Analysis diperoleh, indikator yang menjadi prioritas dalam pelayanan adalah: (1) Kecepatan pelayanan, (2) Kesopanan dan keramahan petugas dalam memberikan pelayanan. Indikator yang perlu dipertahankan kinerjanya adalah: (1) Pemahaman tentang kemudahan prosedur pelayanan; (2)Tanggungjawab petugas dalam memberikan pelayanan; (3) Kesesuaian antara biaya yang dibayarkan dengan biaya yang ditetapkan; dan, (4) Ketepatan pelaksanaan terhadap jadual waktu pelayanan.
\end{abstract}

Kata kunci: indeks kepuasan masyarakat, kualitas pelayanan publik

\section{PENDAHULUAN}

Pemberian pelayanan publik oleh aparatur pemerintah kepada masyarakat merupakan implikasi dari fungsi aparat negara sebagai pelayan masyarakat sehingga kedudukan aparatur pemerintah dalam pelayanan umum (public services) sangat strategis karena akan menentukan sejauhmana pemerintah mampu memberikan pelayanan yang sebaikbaiknya bagi masyarakat dan sejauhmana negara telah menjalankan perannya dengan baik sesuai dengan tujuan pendiriannya. Perkembangan kehidupan masyarakat yang sangat dinamis seiring dengan tingkat kehidupan masyarakat yang semakin baik, merupakan indikasi dari empowering yang dialami oleh masyarakat. Hal ini berarti masyarakat semakin sadar akan apa yang menjadi hak dan kewajibannya sebagai warga negara dalam hidup bermasyarakat, berbangsa dan bernegara. Masyarakat semakin berani untuk mengajukan tuntutan, keinginan dan aspirasinya kepada pemerintah. Masyarakat semakin kritis dan semakin berani untuk melakukan kontrol terhadap apa yang dilakukan oleh pemerintahnya. Kesadaran akan hak-hak 
sipil yang terjadi di masyarakat tidak lepas dari pendidikan politik yang terjadi selama ini.

Pelayanan publik merupakan tanggungjawab pemerintah dan dilaksanakan oleh instansi pemerintah, baik itu di pusat, di Daerah, dan dilingkungan Badan Usaha Milik Negara. Pelayanan publik berbentuk pelayanan barang publik maupun pelayanan jasa. Dewasa ini masyarakat semakin terbuka dalam memberikan kritik bagi pelayanan publik. Oleh sebab itu substansi administrasi sangat berperan dalam mengatur dan mengarahkan seluruh kegiatan organisasi pelayanan dalam mencapai tujuan.

Kualitas pelayanan merupakan suatu kondisi dimana tercipta hubungan yang dinamis antara pengguna maupun pemberi layanan, baik jasa, manusia. Pelayanan publik berkaitan erat dengan kemampuan, dayatanggap, ketepatan waktu, dan sarana prasarana yang tersedia. Apabilalayanan yang diberikan sudah sesuai dengan yang diharapkan oleh pengguna layanan, maka dapat dikatakan pelayanan tersebut merupakan pelayanan yang berkualitas. Sebaliknya jika layanan yang diberikan tidak sesuai dengan harapan pengguna layanan, maka dapat dikatakan pelayanan tersebut tidak berkualitas. Baik buruknya kualitas layanan bukan berdasarkan sudut pandang atau persepsi penyedia jasa/layanan melainkan berdasarkan pada persepsi konsumen dan aturan atau ketentuan tentang kualitas pelayanan.

Dengan perkembangan taraf kehidupan manusia maka tututan pelayanan publik semakin menigkat pula. Pelanggan tidak hanya mengharapkan terpenuhinya kebutuhan, tetapi lebih dari itu adalah kualitas pelayanan yang mereka dapatkan, seperti ketersediaan air bersih yang mampu memberikan kepuasan pada pelanggannya dalam hal ini yang berperan adalah PDAM.

PDAM Bandarmasih kota Banjarmasin sebagai perusahaan daerah yang bergerak dibidang pengadaan air bersih dalam menjalankan usahanya selain bertujuan untuk mendapatkan keuntungan juga diharapkan mampu untuk menyediakan air bersih bagi masyarakat kota Banjarmasin dengan pelayanan yang berkualitas sesuai harapan pelanggannya.

Perusahaan Daerah Air Minum (PDAM) Bandarmasih kota Banjarmasin telah berupaya memberikan pelayanan terbaiknya untuk memenuhi kebutuhan air bersih di kota Banjarmasin, namun dalam perjalanannya sering mendapat keluhan dari masyarakat atau pelanggannya. Keluhan masyarakat atau pelanggan mengenai semakin sulitnya untuk mendapatkan air bersih tampaknya masih menjadi kendala yang sepenuhnya belum dapat diatasi oleh pemerintah daerah dalam hal ini PDAM Bandarmasih kota Banjarmasin.

Jumlah keluhan masyarakat/pelanggan PDAM Bandarmasih kota Banjarmasin setiap bulannya mengalami peningkatan dengan jumlah tertinggi pada bulan September yakni sebanyak 2.436 keluhan/orang. Pengaduan terbesar adalah mengenai masalah ketidaklancaran air, selain itu juga mengenai kebocoran pipa. Dari uraian di atas maka penulis tertarik untuk meneliti mengenai Analisis Indeks Kepuasan Mayarakat (IKM) dan pemetaan kualitas Pelayanan Publik pada PDAM Bandarmasih di Banjarmasin.

\section{Tinjauan Teori}

Kepuasan masyarakat merupakan faktor yang sangat penting dan menentukan keberhasilan penyelenggaraan pelayanan publik karena masyarakat adalah konsumen dari produk layanan yang dihasilkannya. Hal ini didukung oleh pernyataan Hoffman dan Beteson (1997, p.270), yaitu: "without custumers, the service firm has no reason to exist". Definisi kepuasan masyarakat menurut Mowen (1995, p.511): "Costumers satisfaction is defined as the overall attitudes regarding goods or services after its acquisition and uses". Oleh karena itu, penyelenggara pelayanan publik harus 
dapat memenuhi kebutuhan dan keinginan masyarakat sehingga mencapai kepuasan masyarakat dan lebih jauh lagi kedepannya dapat dicapai kesetiaan masyarakat. Sebab, bila tidak dapat memenuhi kebutuhan dan kepuasan masyarakat sehingga menyebabkan ketidakpuasan masyarakat mengakibatkan kesetiaan masyarakat akan suatu produk menjadi luntur dan beralih ke produk atau layanan yang disediakan oleh badan usaha yang lain.

Untuk mengukur kepuasan masyarakat digunakan atribut yang berisi tentang bagaimana masyarakat menilai suatu produk atau layanan yang ditinjau dari sudut pandang pelanggan. Menurut Dutka (1994, p.41), kepuasan masyarakat dapat diukur melalui atribut-atribut pembentuk kepuasan yang terdiri atas:

a. Value to price relationship. Hubungan antara harga yang ditetapkan oleh badan usaha untuk dibayar dengan nilai/manfaat yang diperoleh masyarakat.

b. Product value adalah penilaian dari kualitas produk atau layanan yang dihasilkan suatu badan usaha.

c. Product benefit adalah manfaat yang diperoleh masyarakat dari mengkosumsi produk yang dihasilkan oleh badan usaha.

d. Product feature adalah ciri-ciri atau karakteristik tertentu yang mendukung fungsi dasar dari suatu produk sehingga berbeda dengan produk yang ditawarkan pesaing.

e. Product design adalah proses untuk merancang tampilan dan fungsi produk.

f. Product reliability and consistency adalah kekakuratan dan keandalan produk yang dihasilkan oleh suatu badan usaha.

g. Range of product ar services adalah macam dari produk atau layanan yang ditawarkan oleh suatu badan usaha.

Kemudian attribute related to service meliputi:

a. Guarantee or waranty adalah jaminan atau garansi yang diberikan oleh badan usaha dan diharapkan dapat memuaskan masyarakat.

b. Delivery communication adalah pesan atau informasi yang disampaikan oleh badan usaha kepada masyarakatnya.

c. Complain handling adalah sikap badan usaha dalam menangani keluhankeluhan atau pengaduan.

d. Resolution of problem adalah tanggapan yang diberikan badan usaha dalam membantu memecahkan masalah masyarakat yang berkaitan dengan layanan yang diterimanya.

Selanjutnya attributes related to the purchase meliput:

a. Courtesy adalah kesopanan, perhatian dan keramahan pegawai.

b. Communication adalah kemampuan pegawai dalam melakukan komunikasi dengan masyarakat pelanggan.

c. Ease or convinience of acquisition adalah kemudahan yang diberikan oleh badan usaha untuk mendapatkan produk atau layanan yang ditawarkan.

d. Company reputation adalah baik tidaknya reputasi yang dimiliki oleh badan usaha dalam melayani masyarakat.

e. Company competence adalah baik tidaknya kemampuan badan usaha dalam melayani masyarakat

Menurut Zeithaml-ParasuramanBerry untuk mengetahui kualitas pelayanan yang dirasakan secara nyata oleh konsumen, ada indikator ukuran kepuasan konsumen yang terletak pada 5 dimensi kualitas pelayanan menurut apa yang dikatakan konsumen. Kelima dimensi servqual itu mencakup beberapa sub dimensi sebagai berikut:

a. Tangibles (kualitas pelayanan yang berupa sarana fisik perkantoran, komputerisasi administrasi, ruang tunggu dan tempat informasi). Dimensi ini berkaitan dengan kemodernan peralatan yang digunakan, daya tarik fasilitas yang digunakan, kerapian petugas serta kelengkapan peralatan penunjang (pamlet atau flow chart). 
b. Reliability (kemampuan dan keandalan untuk menyediakan pelayanan yang terpercaya). Dimensi berkaitan dengan janji menyelesaikan sesuatu seperti diinginkan, penanganan keluhan konsumen, kinerja pelayanan yang tepat, menyediakan pelayanan sesuai waktu yang dijanjikan serta tuntutan pada kesalahan pencatatan.

c. Responsiveness (kesanggupan untuk membantu dan menyediakan pelayanan secara cepat dan tepat, serta tanggap terhadap keinginan konsumen). Dimensi responsiveness mencakup antara lain: pemberitahuan petugas kepada konsumen tentang pelayanan yang diberikan, pemberian pelayanan dengan cepat, kesediaan petugas memberi bantuan kepada konsumen serta petugas tidak pernah merasa sibuk untuk melayani permintaan konsumen.

d. Assurance (kemampuan dan keramahan serta sopan sanun pegawai dalam meyakinkan kepercayaan konsumen). Dimensi assurance berkaitan dengan perilaku petugas yang tetap percaya diri pada konsumen, perasaan aman konsumen dan kemampuan (ilmu pengetahuan) petugas untuk menjawab pertanyaan konsumen.

e. Emphaty (sikap tegas tetapi penuh perhatian dari pegawai terhadap konsumen). Dimensi emphaty memuat antara lain: pemberian perhatian individual kepada konsumen, ketepatan waktu pelayanan bagi semua konsumen, peusahaan memiliki petugas yang memberikan perhatian khusus pada konsumen, pelayanan yang melekat di hati konsumen dan petugas yang memahami kebutuhan spesifik dari pelanggannya.

Servqual atau kualitas pelayanan mengkaitkan dua dimensi sekaligus, yaitu satu pihak penilaian servqual pada dimensi konsumen (customer). Sedangkan di pihak lain juga dapat dilakukan pada dimensi provider atau secara lebih dekat lagi adalah terletak pada kemampuan kualitas pelayanan yang diberikan oleh " orangorang yang melayani " dari tingkat manajerial sampai ke tingkat front line service. Kedua dimensi tersebut dapat saja terjadi kesenjangan atau gap antara harapan-harapan dan kenyataan-kenyataan yang dirasakan konsumen dengan persepsi manajemen terhadap harapan-harapan konsumen tersebut. Hasil penelitian Zeithaml, dkk menggambarkan adanya 4 kesenjangan atau gap tersebut. Gap 1 disebut juga "ketidaktahuan tentang apa yang konsumen harapkan" (not knowing what customers expect). Gap ini terjadi pada dimensi konsumendengan dimensi manajemen tingkat atas. Faktor-faktor kunci yang menjadi penyebab adalah: 1) Perusahaan atau organisasi kurang orientasi pada riset pasar atau kurang menggunakan temuan-temuan riset yang berfungsi untuk pengambilan keputusan tentang keinginan ataupun keluhan konsumen, 2) Ketidakcukupan komunikasi ke atas, yaitu arus informasi yang menghubungkan pelayanan di tingkat front line service dengan kemauan di tingkat atas (misscommunication), 3) terlalu banyaknya tingkatan atau hierarki manajemen. Gap 2 disebut sebagai "kesalahan standarisasi kualitas pelayanan "(the wrong quality service standars). Faktor-faktor kunci yang menjadi penyebab pada gap ini adalah: 1) komitmen pada manajemen belum memadai terhadap kualitas pelayanan, 2) Persepsi mengenai ketidaklayakan, 3) Tidak adanya standarisasi tugas, 4) Tidak terdapatnya penentuan tujuan.Gap 3 disebut sebagai kesenjangan kinerja pelayanan (the service performance gap). Tidak terdapatnya spesifikasi atau suatu citra pelayanan yang khas pada suatu organisasi akan menyebabkan kesenjangan pada penyampaian pelayanan pada konsumen. Faktor kunci yang menjadi penyebab utama antara lain: 1) Ketidakjelasan peran (role ambiguity) atau 
kecenderungan yang menimpa pegawai pemberi pelayanan terhadap kondisi bimbang dalam memberikan pelayanan karena tidak terdapatnya kepastian/standarisasi tugas-tugas mereka, 2) Konflik peran (role conflict), kecenderungan pegawai merasa tidak memiliki kemampuan untuk memuaskan pelanggan, 3) Ketidakcocokkan antara pegawai dengan tugas yang dikerjakan, 4) Ketidakcocokkan antara teknologi dengan tugasyang dikerjakan, 5) Ketidakcocokkan sistem pengendalian atasan, 6) Kekurangan pengawasan, dan 7) Kekurangan kerja tim. Gap 4 disebut sebagai Ketidaksesuaian antara janji yang diberikan dengan pelayanan yang diberikan (when promises do not macth delivery). Faktor-faktor kunci yang berperan sebagai penyebab gap ini adalah: 1) Tidak memadainya komunikasi horizontal, 2) Kecenderungan memberikan janji kepada konsumen secara berlebihan (muluk-muluk).

Tujuan pelayanan publik pada dasarnya adalah memuaskan masyarakat sebagai suatu kewajiban negara terhadap warganya. Untuk mencapai kepuasan tersebut, dituntut kualitas pelayanan yang dapat diukur dari:

a. Transparansi, yaitu pelayanan yang bersifat terbuka, mudah dan dapat diakses oleh semua pihak yang membutuhkan dan disediakan secara memadai serta mudah dimengerti.

b. Akuntabilitas, yaitu pelayanan yang dapat dipertanggung jawabkan dengan ketentuan peraturan perundangundangan.

c. Kondisional, yaitu pelayanan yang sesuai dengan kondisi dan kemampuan pemberi dan penerima pelayanan dengan tetap berpegang pada prinsip efisiensi dan efektivitas.

d. Partisipatif, yaitu pelayanan yang dapat mendorong peran serta masyarakat dalam penyelenggaraan pelayanan publik dengan memperhatikan aspirasi, kebutuhan dan harapan masyarakat. e. Kesamaan hak, yaitu pelayanan yang tidak melakukan diskriminasi dilihat dari aspek apapun, khususnya suku, ras, agama, golongan, status sosial dan lain-lain.

f. Keseimbangan hak dan kewajiban, yaitu pelayanan yang mempertimbangkan aspek keadilan antara pemberi dan penerima pelayanan (Sinambela 2006:6).

Gasperz, Vincent, (1997:5) memberi pengertian kualitas pelayanan dengan menyatakan bahwa: "Kualitas diartikan segala sesuatu yang menentukan kepuasan pelanggan dan upaya perubahan kearah perbaikan terus-menerus, sehingga dikenal istilah Q=MATCH (Quality=Meets Agreed and Changes)". Definisi kualitas dikemukakan pula oleh Juran, Jasep M. (dalam Tjiptono, Fandy, 2000:53) mendefinisikan kualitas dengan menyatakan bahwa: "Kualitas sebagai cocok/sesuai untuk digunakan (Fitness for $U s$ ) yang mengandung pengertian bahwa suatu produk atau jasa harus dapat memenuhi apa yang diharapkan oleh pemakainya".

Ada tiga bentuk dasar pelayanan. Ketiga fungsi ini adalah layanan dengan lisan, layanan dengan tulisan dan layanan melalui perbuatan.

1. Layanan dengan lisan diberikan oleh personil yang bertugas memberikan layanan informasi dari bidang lainnya yang tugasnya memberikan penjelasan kepada pihak yang memerlukan. Dalam suatu organisasi, layanan ini biasanya diberikan oleh bagian Hubungan Masyarakat (Humas) atau yang semacamnya.

Beberapa syarat yang dipenuhi dalam layanan lisan ini agar bisa berhasil sesuai dengan yang diharapkan adalah sebagai berikut:

a. Mampu memberikan penjelasan yang diperlukan dengan lancar, singkat dengan jelas, sehingga memuaskan para pengguna jasa.

b. Bersikap sopan dan ramah. Dengan bersikap yang sopan tidak melayani 
orang-orang yang sekedar hanya ingin ngobrol.

c. Tidak membuang-buang waktu dengan ngobrol atau dengan membicarakan hal-hal yang tidak ada manfaatnya.

2. Layanan dengan tulisan. Layanan ini merupakan bentuk layanan yang paling efisien dan paling banyak digunakan atau dipraktekkan terlebih-lebih dalam era globalisasi, dimana layanan bisa diberikan dalam jarak jauh. Suatu hal yang perlu diperhatikan dalam layanan ini adalah kecepatan pengelolaan masalah dan proses penyelesaiannya. Layanan tulisan ini terdiri dari dua golongan, yaitu:

a. Layanan berupa petunjuk/informasi dan yang sejenis dengan itu yang ditunjukkan kepada orang-orang yang berkepentingan.

b. Layanan tertulis berupa reaksi atas permohonan, keluhan, laporan, ataupun pemberitahuan.

3. Layanan dengan perbuatan. Layanan ini banyak dilakukan oleh petugas-petugas tingkat menengah ke bawah dengan tingkat keahlian atau keterampilan yang memadai. Layanan ini jarang muncul sendirian, karena ia lebih sering muncul bersamaan dengan layanan secara lisan. Namun demikian, layanan ini memiliki spesifikasi tertentu yang membedakannya dengan layanan lisan, yaitu orang tidak hanya membutuhkan penjelasan, tetapi juga memerlukan perbuatan atau tindakan atau hasil perbuatan.

\section{Mengukur Kepuasan Masyarakat dan Kualitas Pelayanan Publik Perspektif Pemerintah}

Berkembangnya era servqual juga memberi inspirasi pemerintah Indonesia untuk memperbaiki dan meningkatkan kinerja pelayanan sektor publik. Salah satu produk peraturan pemerintah terbaru tentang pelayanan publik yang telahdi keluarkan untuk melakukan penilaian dan evaluasi terhadap kinerja unit pelayanan publik instansi pemerintah adalah
Keputusan Menteri Pendayagunaan Aparatur Negara Nomor: KEP25/M.PAN/2/2004 tanggal 24 Pebruari 2004 tentang Pedoman Penyusunan Indeks Kepuasan Masyarakat Unit Pelayanan Instansi Pemerintah. Meliputi 14 indikator yang relevan, valid, dan reliable untuk melakukan pengukuran atas indeks kepuasan masyarakat akan pelayanan publik. Kemudian definisi Pelayanan publik menurut Kepmen ini adalah segala kegiatan pelayanan yang dilaksanakan oleh penyelenggara pelayanan publik sebagai upaya pemenuhan kebutuhan penerima layanan, maupun dalam rangka pelaksanaan ketentuan peraturan perundang-undangan. Hal yang baru dalam keputusan ini antara lain mencantumkan kuesioner untuk melakukan survei, juga mencakup langkah-langkah penyusunan Indeks Kepuasan Masyarakat (IKM) serta adanya ketentuan tentang "jumlah responden minimal 150 orang" yang dipilih secara acak, dengan dasar ("jumlah unsur" +1$) \times 10=(14+1) \times 10=150$ responden.

Selanjutnya dalam mengumpulkan, mengolah dan menganalisis beberapa dimensi/atrubut atau kriteria mengenai kualitas pelayanan yang telah dikembangkan oleh beberapa ahli administrasi. Hal ini dimaksudkan untuk mempermudah menjabarkan 14 indikator dalam keputusan menteri pendayagunaan aparatur negara di atas ke dalam sub-sub indikator sehingga nantinya akan mempermudah pemahaman para responden dalam memberikan tanggapan atas pertanyaan yang berkaitan dengan indikator-indikator tersebut sebagai untuk dasar pengukuran Indeks Kepuasan Masyarakat. Kemudian Ke-14 indikator yang akan dijadikan instrumen pengukuran berdasarkan keputusan menteri pendayagunaan aparatur negara di atas adalah sebagai berikut:

a. Prosedur pelayanan, yaitu kemudahan tahapan pelayanan yang diberikan kepada masyarakat dilihat dari sisi kesederhanaan

alur 
pelayananSehubungan dengan hal di atas, dalam sendi-sendi pelayanan prima seperti yang dikutip Warella (1997 : 31) menyebutkan bahwa untuk menilai pelayanan publik yang berkualitas dapat digunakan kriteriakriteria antara lain (1) kesederhanaan yaitu bahwa prosedur atau tata cara pelayanan diselenggarakan secara mudah, lancar, cepat, tidak berbelitbelit, mudah dipahami dan dilaksanakan oleh yang meminta pelayanan, (2) Adanya kejelasan dan kepastian mengenai prosedur atau tatacara pelayanan, (3) Adanya keterbukaan dalam prosedur pelayanan. Kemudian menurut Carlson dan Schwartz (dalam denhardt, 2003 : 61) menyatakan bahwa ukuran komprehensif untuk servqual sektor publik antara lain (1) Convenience (kemudahan) yaitu ukuran dimana pelayanan pemerintah adalah mudah diperoleh dan dilaksanakan masyarakat. Sementara itu salah satu unsur pokok dalam menilai kualitas jasa yang dikembangkan Tjiptono (2012 : 14) antara lain (1) Accessibility and Flexibility dalam arti sistem operasional atau prosedur pelayanan mudah diakses dan dirancang fleksibel menyesuaikan permintaan dan keinginan pelanggan.

b. Persyaratan pelayanan, yaitu persyaratan teknis dan administratif yang diperlukan untuk mendapatkan pelayanan sesuai dengan jenis pelayanannya. Sehubungan dengan hal di atas, dalam sendi-sendi pelayanan prima seperti yang dikutip Warella (1997:31) menyebutkan bahwa untuk menilai pelayanan publik yang berkualitas dapat digunakan kriteriakriteria antara lain (1) Adanya kejelasan persyaratan pelayanan baik teknis maupun administrasi, (2) Keterbukaan mengenai persyaratan pelayanan, (3) Efisiensi persyaratan dalam arti bahwa dibatasi pada hal-hal yang berkaitan langsung dengan pelayanan serta dicegah adanya pengulangan pemenuhan persyaratan.

c. Kejelasan petugas pelayanan, yaitu keberadaan dan kepastian petugas yang memberikan pelayanan (nama, jabatan, serta kewenangan dan tanggung jawab). Sehubungan dengan hal di atas, menurut Gaspersz (1997 : 2), atribut atau dimensi yang harus diperhatikan dalam perbaikan kualitas pelayanan antara lain (1) Kemudahan mendapatkan pelayanan yang berkaitan dengan berkaitan dengan penerimaan pelayanan dan penanganan keluhan dari pelanggan eksternal. Kemudian Morgan dan Murgatroyd (1994) mengemukakan beberapa kriteria persepsi pelanggan terhadap kualitas pelayanan antara lain

Responsiveness yaitu kesediaan untuk membantu pelanggan dengan menyediakan pelayanan yang cocok seperti yang mereka inginkan, (2) Access yaitu mudah melakukan kontak dengan penyedia jasa.

d. Kedisiplinan petugas pelayanan, yaitu kesungguhan petugas dalam memberikan pelayanan terutama terhadap konsistensi waktu kerja sesuai ketentuan yang berlaku. Sehubungan dengan hal di atas, menurut Morgan dan Murgatroyd (1994), beberapa kriteria persepsi pelanggan terhadap kualitas pelayanan antara lain (1) Reliability yaitu kemampuan untuk melaksanakan pelayanan yang telah dijanjikan dengan tepat waktu, (2) Credibility yaitu dapat dipercaya, jujur dan mengutamakan kepentingan pelanggan. Kemudian menurut Carlson dan Schwarz (dalam Denhardt, 2003 : 61) yang mengatakan bahwa ukuran yang komprehensif untuk servqual sektor publik antara lain (1) Reliability (keandalan) yaitu menilai tingkat dimana pelayanan pemerintah disediakan secara benar dan tepat waktu, (2) Personal attention (perhatian kepada orang) yaitu ukuran tingkat dimana aparat menyediakan 
informasi kepada masyarakat dan bekerja sungguh-sungguh dengan mereka untuk memenuhi kebutuhan mereka.

e. Tanggung jawab petugas pelayanan yaitu kejelasan wewenang dan tanggung jawab dalam penyelenggaraan dan penyelesaian pelayanan. Sehubungan dengan hal di atas, dalam sendi-sendi pelayanan prima seperti yang dikutip Warella (1997 : 31) menyebutkan bahwa untuk menilai pelayanan publik yang berkualitas dapat digunakan kriteriakriteria antara lain (1) Kejelasan dan kepastian unit kerja atau pejabat yang berwenang dan bertanggung jawab dalam memberikan pelayanan, (2) Keterbukaan mengenai satuan kerja/ pejabat penanggungjawab pemberi pelayanan.

f. Kemampuan petugas pelayanan, yaitu tingkat keahlian dan keterampilan yang dimiliki petugas dalam memberikan/menyelesaikan pelayanan kepada masyarakat. Sehubungan dengan hal di atas, menurut Tjiptono (2002 : 14) mengemukakan beberapa unsur untuk menilai kualitas jasa yang antara lain (1) Profesionalism and Skill; yang berkaitan dengan pengetahuan dan keterampilan (intelektual, fisik, administrasi maupun konseptual) yang dibutuhkan untuk memecahkan masalah pelanggan secara profesional. Kemudian Morgan dan Murgatroyd (1994) mengemukakan beberapa kriteria persepsi pelanggan terhadap kualitas pelayanan antara lain (1) Competence, yaitu menyangkut pengetahuan dan keterampilan yang diperlukan untuk melaksanakan pelayanan.

g. Kecepatan pelayanan, yaitu target waktu pelayanan dapat diselesaikan dalam waktu yang telah ditentukan oleh unit penyelenggara pelayanan. Sehubungan dengan hal di atas, menurut Gaspersz (1997:2 ), atribut atau dimensi yang harus diperhatikan dalam perbaikan kualitas pelayanan antara lain (1) Ketepatan waktu pelayanan, dimana hal yang perlu diperhatikan berkaitan dengan waktu tunggu dan waktu proses. Kemudian dalam sendi-sendipelayanan prima seperti yang dikutip Warella (1997 : 31) menyebutkan bahwa untuk menilai pelayanan publik yang berkualitas dapat digunakan kriteria-kriteria antara lain (1) Keterbukaan waktu penyelesaian, (2) Ketepatan waktu yaitu bahwa pelaksanaan pelayanan publik dapat diseleaikan dalam kurun waktu yang telah ditentukan.

h. Keadilan mendapatkan pelayanan, yaitu pelaksanaan pelayanan dengan tidak membedakan golongan/status masyarakat yang dilayani. Sehubungan dengan hal di atas, menurut Carlson dan Schwartz (dalam denhardt, 2003 : 61) menyatakan bahwa ukuran komprehensif untuk servqual sektor publik antara lain (1) Fairness (keadilan) yaitu ukuran tingkat dimana masyarakat percaya bahwa pelayanan pemerintah disediakan sama untuk semua orang. Selanjutnya dalam sendisendi pelayanan prima seperti yang dikutip Warella (1997: 31) menyebutkan bahwa untuk menilai pelayanan publik yang berkualitas dapat digunakan kriteria-kriteria antara lain (1) Keadilan yang merata yaitu bahwa cakupan/jangkauan pelayanan harus diusahakan seluas mungkin dengan distribusi yang merata dan diberlakukan.

i. Kesopanan dan keramahan petugas, yaitu sikap dan perilaku petugas dalam memberikan pelayanan kepada masyarakat secara sopan dan ramah serta saling menghargai dan menghormati. Sehubungan dengan hal di atas, menurut Gaspersz (1997: 2), atribut atau dimensi yang harus diperhatikan dalam perbaikan kualitas pelayanan antara lain kesopanan dan keramahan dalam memberikan khususnya interaksi langsung. 
Kemudian Morgan dan Murgatroyd (1994) mengemukakan kriteria persepsi pelanggan terhadapkualitas pelayanan yaitu Courtessy, yaitu sikap sopan, menghargai orang lain, penuh pertimbangan dan persahabatan. Selain itu, menurut Zeithaml dkk salah satu dimensi untuk mengukur kepuasan pelanggan antara lain (1) Assurance yaitu kemampuan dan keramahan serta sopan sanun pegawai dalam meyakinkan kepercayaan konsumen, (2) Emphaty yaitu sikap tegas tetapi penuh perhatian dari pegawai terhadap konsumen.

j. Kewajaran biaya pelayanan, yaitu keterjangkauan masyarakat terhadap besarnya biaya yang ditetapkan oleh unit pelayanan. Sehubungan dengan hal di atas, dalam pelayanan prima seperti yang dikutip Warella (1997: 31)menyebutkan bahwa untuk menilai pelayanan publik yang berkualitas dapat digunakan kriteria-kriteria antara lain (1) Ekonomis yaitu biaya pelayanan harus ditetapkan secara wajar dengan memperhatikan. Kemudian Tjiptono (2002: 14) mengemukakan beberapa unsur untuk menilai kualitas jasa yang antara lain (2) Reputation and Credibility yaitu pelanggan menyakini bahwa operasi dari penyedia jasa dapat dipercaya dan memberikan nilai atau imbalan yang sesuai dengan pengorbanannya atau biayanya.

k. Kepastian biaya pelayanan, yaitu kesesuaian antara biaya yang dibayarkan dengan biaya yang telah ditetapkan. Sehubungan dengan hal di atas, dalam pelayanan prima seperti yang dikutip Warella (1997: 31) menyebutkan bahwa untuk menilai pelayanan publik yang berkualitas dapat digunakan kriteria-kriteria antara lain (1) Kejelasan dan kepastian mengenai rincian biaya/tariffpelayanan dan tatacara pembayarannya, (2) Keterbukaan mengenai rincian biaya/tarif pelayanan.
1. Kepastian jadwal pelayanan, yaitu pelaksanaan waktu pelayanan, sesuai dengan ketentuan yang telah ditetapkan. Sehubungan dengan hal di atas, dalam pelayanan prima seperti yang dikutip Warella (1997: 31) menyebutkan bahwa untuk menilai pelayanan publik yang berkualitas dapat digunakan kriteria-kriteria antara lain (1) Kejelasan dan kepastian yaitu yang menyangkut jadwal waktu penyelesaian pelayanan. Kemudian Carlson dan Schwartz (dalam denhardt, 2003: 61) menyatakan bahwa ukuran komprehensif untuk servqual sektor publik antara lain (1) Reability (keandalan) yaitu menilai tingkat dimana pelayanan pemerintah disediakan secara benar dan tepat waktu.

m. Kenyamanan lingkungan, yaitu kondisi sarana dan prasarana pelayanan yang bersih, rapi dan teratur sehingga dapat memberikan rasa nyaman kepada penerima pelayanan. Sehubungan dengan hal di atas, menurut Gaspersz (1997: 2), atribut atau dimensi yang harus diperhatikan dalam perbaikan kualitas pelayanan antara lain (1) Kenyamanan dalam memperoleh pelayanan yang berkaitan dengan lokasi, ruang tempat pelayanan, kemudahan menjangkau, ketersediaan informasi dan lain-lain, (2) Atribut pendukung pelayanan lainnya yang berkaitan dengan lingkungan, kebersihan, ruang tunggu, fasilitas musik dan lain-lain. Kemudian menurut Zeithaml dkk salah satu dimensi untuk mengukur kepuasan pelanggan antara lain (1) Tangibles yaitu yang berupa sarana fisik perkantoran, komputerisasi administrasi, ruang tunggu, tempat informasi dan lain-lain. Selanjutnya di dalam pelayanan prima seperti yang dikutip Warella (1997: 31) menyebutkan bahwa untuk menilai pelayanan publik yang berkualitas dapat digunakan kriteria-kriteria antara 
lain (2) penilaian fisik lainnya antara lain kebersihan dan kesejukan lingkungan.

n. Keamanan pelayanan, yaitu terjaminnya tingkat keamanan lingkungan unit penyelenggara pelayanan ataupun sarana yang digunakan, sehingga masyarakat merasa tenang untuk mendapatkan pelayanan terhadap resiko-resiko yang diakibatkan dari pelaksanaan pelayanan. Sehubungan dengan hal di atas, menurut Morgan dan Murgatroyd (1994) mengemukakan beberapa kriteria persepsi pelanggan terhadap kualitas pelayanan antara lain (1) Security yaitu bebas dari risiko, bahaya dan keragu-raguan. Kemudian Carlson dan Schwartz (dalam denhardt, 2003: 61) menyatakan bahwa ukuran komprehensif untuk servqual sektor publik antara lain (1) Security yaitu ukuran tingkat dimana pelayanan yang disediakan membuat masyarakat merasa aman dan yakin ketika menerimanya. Selain itu, dalam pelayanan prima seperti yang dikutip Warella (1997: 31) menyebutkan bahwa untuk menilai pelayanan publik yang berkualitas dapat digunakan kriteria-kriteria antara lain (2) Keamanan yaitu proses serta hasil pelayanan dapat memberikan keamanan, kenyamanan dan memberikan kepastian hukum bagi masyarakat.

Dengan demikian, untuk dapat menilai sejauh mana mutu pelayanan publik yang diberikan aparatur pemerintah, memang tidak bias dihindari, bahwa menjadi tolak ukur kualitas pelayanan dapat ditelaah dari kriteria dimensidimensi kualitas pelayanan publik.

\section{METODE PENELITIAN}

\section{Desain Penelitian}

Penelitian ini dilakukan untuk mengetahui kepuasan masyarakat terhadap kualitas pelayanan yang diberikan oleh pihak PDAM Bandarmasih di
Banjarmasin. Hasil perhitungan kuantitatif yang diperoleh disajikan dalam bentuk deskripsi yang berpusat pada makna. Oleh karena itu, penelitian ini merupakan jenis penelitian deskriptif kuanlitatif.

Penelitian ini merupakan penelitian yang bertujuan untuk menjelaskan fenomena yang ada dengan menggunakan angka-angka untuk mencandarkan karakteristik individu atau kelompok (Syamsudin \& Damiyanti, 2011). Penelitian ini menilai sifat dari kondisikondisi yang nampak. Tujuan dalam penelitian ini dibatasi untuk menggambarkan karakteristik sesuatu sebagaimana adanya.

\section{Jenis dan Sumber Data}

Penelitian ini menggunakan jenis data kuanlitatif. Data kuanlitatif diperoleh melalui penyebaran kuesioner yang hasilnya akan diangkakan. Dimana kuesioner tersebut merujuk pada Keputusan Men.PAN Nomor: KEP/25/M.PAN/2/2004 tentang Pedoman Umum Penyusunan Indeks Kepuasan Masyarakat Unit Pelayanan Instansi Pemerintah.Sumber Data yang digunakan adalah data primer yaitu data atau segala informasi yang diperoleh, diamati, dan dicatat oleh peneliti langsung dari hasil kuesioner yang diberikan kepada responden yang menjadi objek penelitian.

\section{Prosedur Pengambilan dan Pengumpulan Data}

Prosedur pengambilan dan pengumpulan data pada penelitian ini adalah sebagai berikut: Sebagai langkah awal penelitian, peneliti akan melakukan observasi, yaitu mengadakan pencatatan secara sistematis dan melakukan pengamatan langsung terhadap objek penelitian. Tujuan observasi adalah untuk memperoleh berbagai data konkret secara langsung di lapangan atau tempat penelitian, dari hasil observasi akan diperoleh gambaran yang jelas tentang masalahnya dan mungkin petunjukpetunjuk tentang cara pemecahannya. 
Peneliti melanjutkan menggunakan wawancara terstruktur yakni dengan kuesioner. Wawancara merupakan suatu teknik pengumpulan data dengan jalan mengadakan komunikasi dengan sumber data. Peneliti melakukan wawancara terstruktur kepada responden, hal-hal yang ditanyakan telah ditetapkan secara rinci.

\section{Populasi dan Sampel}

Dalam penelitian ini populasi adalah keseluruhan individu/masyarakat yang mendapatkan pelayanan pada loket pengaduan gangguan pada PDAM Bandarmasih di Banjarmasin. Metode pengambilan sampel yang digunakan adalah sampel insidensial yaitu penentuan sampel secara „kebetulan" yaitu siapa saja yang secara kebetulan/insidental bertemu dengan peneliti dapat digunakan sebagai sampel, bila dipandang orang yang kebetulan ditemui itu cocok sebagai sumber data. Sugiyono (2005:96). Adapun sampel dalam penelitian ini sebanyak 150 orang. Hal ini sesuai dengan keputusan Men.PAN Nomor: KEP/25/M.PAN/2/2004, bahwa untuk penelitian mengenai Indeks Kepuasan Masyarakat, maka sampel yang digunakan minimal sebanyak 150 responden.

\section{Definisi Operasional Unsur Indeks Kepuasan Masyarakat}

Berdasarkan prinsip pelayanan sebagaimana telah ditetapkan dalam Keputusan Men.PAN Nomor: KEP/25/M.PAN/2/2004, yang kemudian dikembangkan menjadi 14 unsur yang "relevan, valid" dan "reliabel", sebagai unsur minimal yang harus ada untuk dasar pengukuran indeks kepuasan masyarakat adalah sebagai berikut:

1. Prosedur pelayanan, yaitu kemudahan tahapan pelayanan yang diberikan kepada masyarakat dilihat dari sisi kesederhanaan alur pelayanan;

2. Persyaratan Pelayanan, yaitu persyaratan teknis dan administratif yang diperlukan untuk mendapatkan pelayanan sesuai dengan jenis pelayanannya;
3. Kejelasan petugas pelayanan, yaitu keberadaan dan kepastian petugas yang memberikan pelayanan (nama, jabatan serta kewenangan dan tanggung jawabnya);

4. Kedisiplinan petugas pelayanan, yaitu kesungguhan petugas dalam memberikan pelayanan terutama terhadap konsistensi waktu kerja sesuai ketentuan yang berlaku;

5. Tanggung jawab petugas pelayanan, yaitu kejelasan wewenang dan tanggung jawab petugas dalam penyelenggaraan dan penyelesaian pelayanan;

6. Kemampuan petugas pelayanan, yaitu tingkat keahlian dan ketrampilan yang dimiliki petugas dalam memberikan/menyelesaikan pelayanan kepada masyarakat;

7. Kecepatan pelayanan, yaitu target waktu pelayanan dapat diselesaikan dalam waktu yang telah ditentukan oleh unit penyelenggara pelayanan;

8. Keadilan mendapatkan pelayanan, yaitu pelaksanaan pelayanan dengan tidak membedakan golongan/status masyarakat yang dilayani;

9. Kesopanan dan keramahan petugas, yaitu sikap dan perilaku petugas dalam memberikan pelayanan kepada masyarakat secara sopan dan ramah serta saling menghargai dan menghormati;

10. Kewajaran biaya pelayanan, yaitu keterjangkauan masyarakat terhadap besarnya biaya yang ditetapkan oleh unit pelayanan;

11. Kepastian biaya pelayanan, yaitu kesesuaian antara biaya yang dibayarkan dengan biaya yang telah ditetapkan;

12. Kepastian jadual pelayanan, yaitu pelaksanaan waktu pelayanan, sesuai dengan ketentuan yang telah ditetapkan;

13. Kenyamanan lingkungan, yaitu kondisi sarana dan prasarana pelayanan yang bersih, rapi, dan teratur sehingga dapat memberikan rasa nyaman kepada penerima pelayanan; 
14. Keamanan Pelayanan, yaitu terjaminnya tingkat keamanan lingkungan unit penyelenggara pelayanan ataupun sarana yang digunakan, sehingga masyarakat merasa tenang untuk mendapatkan pelayanan terhadap resiko-resiko yang diakibatkan dari pelaksanaan pelayanan.

\section{Pengolahan dan Analisis Data}

Nilai IKM dihitung dengan menggunakan "nilai rata-rata tertimbang" masing-masing unsur pelayanan. Dalam penghitungan indeks kepuasan masyarakat terhadap 14 unsur pelayanan yang dikaji, setiap unsur pelayanan memiliki penimbang yang sama dengan rumus:

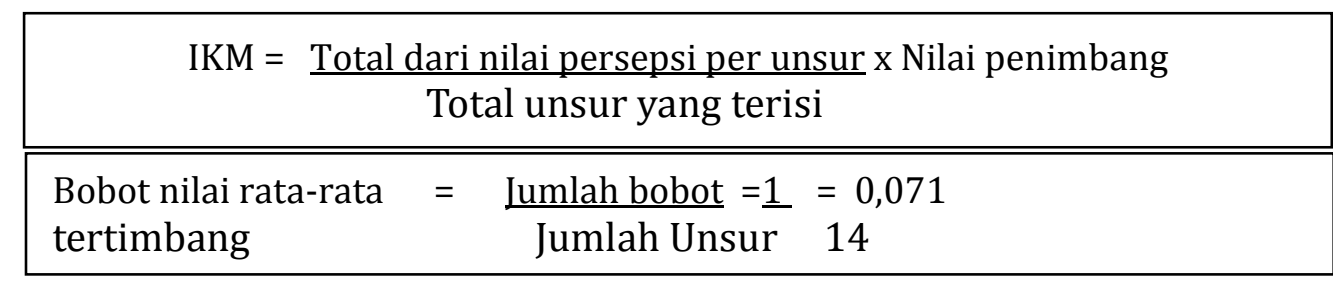

Jumlah nilai dari setiap unit pelayanan diperoleh dari jumlah nilai ratarata setiap unsur pelayanan. Sedangkan nilai indeks komposit (gabungan) untuk setiap unit pelayanan, merupakan jumlah nilai rata-rata dari setiap unsur pelayanan dikalikan dengan penimbang yang sama, yaitu 0,071. Untuk memudahkan interpretasi, nilai IKM dikonversikan dengan nilai dasar 25 ,

Hasil dari perhitungan semua unsur menjadi nilai total IKM, baru dikonversikan dengan tabel nilai persepsi. Mengingat unit pelayanan memiliki karakteristik yang berbeda-beda, maka setiap unit pelayanan dimungkinkan untuk: (a) Menambah unsur yang dianggap relevan, (b) Memberikan bobot yang berbeda terhadap 14 (empat belas) unsur yang dominan dalam unit pelayanan, dengan catatan jumlah bobot seluruh unsur tetap 1 .

Tabel 1. Nilai Persepsi, Interval IKM, Interval Konversi IKM, Mutu Pelayanan dan Kinerja Unit Pelayanan

\begin{tabular}{ccccc} 
Nilai & Nilai & Nilai Interval & Mutu & Kinerja Unit \\
Persepsi & Interval IKM & Konversi IKM & $\begin{array}{c}\text { Pelayanan } \\
\text { Pelayanan }\end{array}$ \\
\hline 1 & $1,00-1,75$ & $25-43,75$ & $\mathrm{D}$ & Tidak baik \\
2 & $1,76-2,50$ & $43,76-62,50$ & $\mathrm{C}$ & Kurang baik \\
3 & $2,51-3,25$ & $62,51-81,25$ & $\mathrm{~B}$ & Baik \\
4 & $3,26-4,00$ & $81,26-100,00$ & $\mathrm{~A}$ & Sangat baik \\
\hline
\end{tabular}

Sumber: Kep.menpan No. 25/2004

Langkah yang sama juga dilakukan untuk pengolahan data perseptual tentang kepentingan dengan menggunakan nilai rata-rata per unsur, namun tidak dikalikan dengan nilai dasarnya. Teknik dasarnya adalah dengan mengidentifikasi atribut kepentingan, dalam hal ini unsur-unsur yang sama dalam penilaian kinerja, kemudian dievaluasi berdasarkan derajat kepentingan program bagi masyarakat penerima, relatif terhadap kepuasan kinerja. Dengan menggunakan nilai ratarata, skor atribut kepentingan dan kepuasan diranking dan diklasifikasikan menjadi kategori rendah sampai tinggi, lalu dipasangkan per unsur, dan kemudian dengan menggunakan program SPSS di plot dalam diagram pencar dan Kartesius (scatter plot dan Kartesius). Kemudian dianalisis termasuk dalam grid kuadran 
kepentingan-kepuasan manakah tiap unsur per program, dan untuk keseluruhan program (Crompton dan Duray, 1985 dalam Kitcharoen, 2004: 22).

Setelah disimpulkan posisi kuadran mana kondisi perseptual masyarakat, baru dilakukan analisis dengan berorientasi pada Important Performance Analysis (selanjutnya disebut IPA). Model analisis IPA mempertimbangkan hubungan antara kepentingan (selanjutnya disebut Important) dengan kepuasan (selanjutnya disebut Performance), dan secara teoritis atribut kinerja suatu produk seharusnya proporsional dengan derajat pentingnya produk tersebut. Dengan kata lain, bagi konsumen nilai kepentingan nampaknya dipandang sebagai refleksi dari nilai relatif beragam atribut kualitas (Slack, 1991 dalam Kitcharoen, 2004: 21).

Diagram Kartesius akan menjabarkan setiap unsur dalam empat bagian (kuadran), yang antara lain adalah sebagai berikut (PSP3 IPB, 20: II-4):

\section{Kuadran A: Concentrate Here} (perbaikan kinerja), menunjukkan bahwa unsur-unsur yang sangat penting bagi masyarakat, akan tetapi unit-unit pelayanan belum melaksanakan sesuai dengan keinginan masyarakat sehingga menimbulkan ketidakpuasan.

Kuadran B: Keep up the Good Work (pertahankan kinerja), menunjukkan bahwa unsur-unsur yang dianggap penting oleh masyarakat telah berhasil dilaksanakan dengan baik dan dapat memuaskan. Oleh karenanya kewajiban unit-unit pelayanan adalah mempertahankan kinerjanya.

Kuadran C: Possible Skill (kinerja berlebihan), menunjukkan bahwa unsurunsur pelayanan yang dianggap kurang penting oleh masyarakat, tetapi telah dijalankan sangat baik oleh unit-unit pelayanan, sehingga sangat memuaskan dan dianggap berlebihan.

Kuadran D: Low Priority (prioritas rendah), menunjukkan bahwa unsur-unsur pelayanan dianggap kurang penting oleh masyarakat dan pelaksanaannya biasabiasa saja oleh unit-unit pelayanan, sehingga dianggap kurang penting dan kurang memuaskan.

Analisis tingkat kesesuaian merupakan perbandingan antara skor ratarata penilaian tingkat kepuasan dengan skor rata-rata penilaian tingkat kepentingan yang dinyatakan dalam persentase (Equivalen=P/I x 100\%). Unsur-unsur tersebut dikatakan telah memenuhi tingkat kesesuaian apabila tingkat kesesuaian lebih dari atau sama dengan tingkat kinerjanya.

\section{HASIL PENELITIAN DAN PEMBAHASAN}

Penilaian Masyarakat terhadap Kinerja dan Kepentingan pada Indikator indikator Kualitas Pelayanan

Penilaian masyarakat terrhadap tingkat kinerja dan tingkat kepentingan pada indikator-indikator kualitas pelayanan dapat dilihat pada tabel berikut: 
Tabel 2. Penilaian Masyarakat terhadap Tingkat Kinerja pada Indikator Kualitas Pelayanan PDAM Bandarmasih

\begin{tabular}{|c|c|c|c|c|c|}
\hline \multirow{2}{*}{ NO } & \multirow{2}{*}{$\begin{array}{c}\text { UNSUR EVALUASI } \\
\text { KUALITAS PELAYANAN }\end{array}$} & \multicolumn{4}{|c|}{ TINGKAT KINERJA (\%) } \\
\hline & & TP1 & KP1 & $\mathbf{P 1}$ & SP1 \\
\hline 1 & Pemahaman tentang kemudahan prosedur pelayanan & 3 & 22 & 60 & 15 \\
\hline 2 & $\begin{array}{l}\text { Kesesuaian persyaratan pelayanan dengan jenis } \\
\text { pelayanan1 }\end{array}$ & 1 & 19 & 59 & 21 \\
\hline 3 & Kejelasan dan kepastian petugas yang melayani & 2 & 19 & 64 & 15 \\
\hline 4 & Kedisiplinan petugas dalam memberikan pelayanan & 0 & 21 & 62 & 17 \\
\hline 5 & $\begin{array}{l}\text { Tanggung jawab petugas dalam memberikan } \\
\text { pelayanan }\end{array}$ & 2 & 19 & 60 & 19 \\
\hline 6 & Kemampuan petugas dalam memberikan pelayanan & 0 & 20 & 65 & 15 \\
\hline 7 & Kecepatan pelayanan & 1 & 33 & 50 & 16 \\
\hline 8 & Keadilan untuk mendapatkan pelayanan & 1 & 14 & 68 & 17 \\
\hline 9 & $\begin{array}{l}\text { Kesopanan dan keramahan petugas dalam } \\
\text { memberikan pelayanan }\end{array}$ & 2 & 22 & 57 & 19 \\
\hline 10 & Kewajaran biaya untuk mendapatkan pelayanan & 2 & 9 & 69 & 20 \\
\hline 11 & $\begin{array}{l}\text { Kesesuaian antara biaya yang dibayarkan dengan } \\
\text { biaya yang ditetapkan }\end{array}$ & 1 & 19 & 57 & 23 \\
\hline 12 & $\begin{array}{l}\text { Ketepatan pelaksanaan terhadap jadwal waktu } \\
\text { pelayanan }\end{array}$ & 1 & 15 & 60 & 24 \\
\hline 13 & Kenyamanan di lingkungan unit pelayanan & 2 & 13 & 71 & 14 \\
\hline 14 & Keamanan pelayanan & 2 & 21 & 60 & 17 \\
\hline
\end{tabular}

Sumber: Data primer, diolah 2018

Keterangan:

TP1: Tidak Puas

KP1: Kurang Puas

P1: Puas

SP1: Sangat Puas

Tabel 3. Penilaian Masyarakat terhadap Tingkat Kepentingan pada Indikator-indikator Kualitas Pelayanan PDAM Bandarmasih

\begin{tabular}{|c|l|c|c|c|c|}
\cline { 2 - 6 } NO & \multicolumn{1}{|c|}{ UNSUR EVALUASI } & \multicolumn{5}{c|}{ TINGKAT KEPENTINGAN (\%) } \\
\cline { 2 - 6 } & \multicolumn{1}{|c|}{ KUALITAS PELAYANAN } & TP2 & KP2 & P2 & SP2 \\
\hline 1 & Pemahaman tentang kemudahan prosedur pelayanan & 1 & 1 & 61 & 37 \\
\hline 2 & $\begin{array}{l}\text { Kesesuaian persyaratan pelayanan dengan jenis } \\
\text { pelayanan }\end{array}$ & 0 & 0 & 73 & 27 \\
\hline 3 & Kejelasan dan kepastian petugas yang melayani & 0 & 0 & 65 & 35 \\
\hline 4 & Kedisiplinan petugas dalam memberikan pelayanan & 0 & 0 & 67 & 33 \\
\hline 5 & $\begin{array}{l}\text { Tanggung jawab petugas dalam memberikan } \\
\text { pelayanan }\end{array}$ & 0 & 0 & 62 & 38 \\
\hline 6 & Kemampuan petugas dalam memberikan pelayanan & 0 & 0 & 67 & 33 \\
\hline 7 & Kecepatan pelayanan & 0 & 0 & 51 & 49 \\
\hline 8 & Keadilan untuk mendapatkan pelayanan & 0 & 0 & 69 & 31 \\
\hline 9 & $\begin{array}{l}\text { Kesopanan dan keramahan petugas dalam } \\
\text { memberikan pelayanan }\end{array}$ & 0 & 0 & 58 & 42 \\
\hline
\end{tabular}




\begin{tabular}{|c|l|c|c|c|c|}
10 & Kewajaran biaya untuk mendapatkan pelayanan & 0 & 0 & 70 & 30 \\
\hline 11 & $\begin{array}{l}\text { Kesesuaian antara biaya yang dibayarkan dengan } \\
\text { biaya yang ditetapkan }\end{array}$ & 0 & 0 & 59 & 41 \\
\hline 12 & $\begin{array}{l}\text { Ketepatan pelaksanaan terhadap jadwal waktu } \\
\text { pelayanan }\end{array}$ & 0 & 0 & 62 & 38 \\
\hline 13 & Kenyamanan di lingkungan unit pelayanan & 0 & 0 & 72 & 28 \\
\hline 14 & Keamanan pelayanan & 0 & 0 & 66 & 34 \\
\hline
\end{tabular}

Sumber: Data primer, diolah 2018

Keterangan:

TP2: Tidak Penting

KP2: Kurang Penting

P2: Penting

SP2: Sangat Penting

\section{Indeks Kepuasan Masyarakat (IKM) terhadap Pelayanan.}

Untuk melihat indek kepuasan masyarakat (IKM), perbedaan antara tingkat kinerja $(\mathrm{Kn})$ dan tingkat kepentingan $(\mathrm{Kp})$ untuk pelayanan PDAM Bandarmasih dapat dilihat pada tabel di bawah berikut ini:

Tabel 4. Perbandingan Nilai Rata-Rata antara Kinerja-Kepentingan Pelayanan pada PDAM Bandarmasih

\begin{tabular}{|c|c|c|c|c|c|c|}
\hline NO & UNSUR EVALUASI & Kр & Kn & GAB & $\begin{array}{l}\text { KESESUAIAN } \\
\%\end{array}$ & IKM \\
\hline 1 & $\begin{array}{l}\text { Pemahaman tentang kemudahan prosedur } \\
\text { pelayanan }\end{array}$ & 3,32 & 2.87 & 0,45 & 86,64 & \multirow{12}{*}{$\begin{array}{c}2,93 / \\
73,36 / \\
\text { B } \\
\text { (baik) }\end{array}$} \\
\hline 2 & $\begin{array}{l}\text { Kesesuaian persyaratan pelayanan dengan } \\
\text { jenis pelayanan }\end{array}$ & 3.37 & 3,00 & 0,37 & 89,02 & \\
\hline 3 & $\begin{array}{l}\text { Kejelasan dan kepastian petugas yang } \\
\text { melayani }\end{array}$ & 3,34 & 2,92 & 0,42 & 87,74 & \\
\hline 4 & $\begin{array}{l}\text { Kedisiplinan petugas dalam memberikan } \\
\text { pelayanan }\end{array}$ & 3,31 & 2,89 & 0,42 & 87,31 & \\
\hline 5 & $\begin{array}{l}\text { Tanggung jawab petugas dalam memberikan } \\
\text { pelayanan }\end{array}$ & 3,35 & 2,97 & 0,38 & 88,66 & \\
\hline 6 & $\begin{array}{l}\text { Kemampuan petugas dalam memberikan } \\
\text { pelayanan }\end{array}$ & 3,32 & 2,92 & 0,40 & 87,95 & \\
\hline 7 & Kecepatan pelayanan & 3,35 & 2,80 & 0,55 & 83,58 & \\
\hline 8 & Keadilan untuk mendapatkan pelayanan & 3,31 & 3,00 & 0,31 & 90,63 & \\
\hline 9 & $\begin{array}{l}\text { Kesopanan dan keramahan petugas dalam } \\
\text { memberikan pelayanan }\end{array}$ & 3,46 & 2,93 & 0,53 & 84,68 & \\
\hline 10 & $\begin{array}{l}\text { Kewajaran biaya untuk mendapatkan } \\
\text { pelayanan }\end{array}$ & 3,31 & 3,06 & 0,25 & 92,45 & \\
\hline 11 & $\begin{array}{l}\text { Kesesuaian antara biaya yang dibayarkan } \\
\text { dengan biaya yang ditetapkan }\end{array}$ & 3,42 & 3,01 & 0,41 & 88,01 & \\
\hline 12 & $\begin{array}{l}\text { Ketepatan pelaksanaan terhadap jadwal waktu } \\
\text { pelayanan }\end{array}$ & 3,30 & 3,07 & 0,23 & 93,03 & \\
\hline
\end{tabular}




\begin{tabular}{|c|l|l|l|l|l|}
13 & Kenyamanan di lingkungan unit pelayanan & 3,41 & 2,96 & 0,45 & 86,80 \\
\hline 14 & Keamanan pelayanan & 3,39 & 2,93 & 0,46 & 86,43 \\
\hline Rata-rata & 3,37 & 2,87 & 0,40 & 88,07 \\
\hline
\end{tabular}

Sumber: Data primer, diolah 2018

Berdasarkan Tabel di atas maka dapat diketahui nilai IKM untuk pelayanan PDAM Bandarmasih di Banjarmasin sebesar 2,93 atau dikonversi sama dengan 73,36. Hal ini dapat dikatakan bahwa indeks kepuasan masyarakat terhadap pelayanan yang telah dilakukan PDAM Bandarmasih padamutu pelayanan $\mathrm{B}$ atau kinerja pelayanan baik.

Kalau dilihat dari tingkat kesesuaian yang merupakan perbandingan antara tingkat kinerja dengan tingkat kepentingan, dimana tingkat kinerja adalah segala sesuatu yang telah dilakukan PDAM Bandarmasih untuk melayani masyarakat, sedangkan tingkat kepentingan adalah harapan dari masyarakat mengenai pelayanan yang diberikan kepada masyarakat. Dalam hal ini apabila tingkat kesesuaian mendekati $100 \%$ dan berada di atas rata-rata, maka dapat dikatakan tingkat kesesuaian sudah baik, namun bila angka tingkat kesesuaian berada di bawah rata-rata, maka dapat dikatakan belum terdapat kesesuaian antara tingkat kepentingan dengan tingkat harapan masyarakat terhadap pelayanan PDAM Bandarmasih. masyarakat dapat dikatakan puas terhadap kinerja. Tetapi apabila tingkat kesesuaian kurang dari $100 \%$ maka masyarakat belum merasa puas terhadap pelayanan yang mereka terima, artinya pelayanan yang diberikan selama ini masih belum memenuhi harapan masyarakat.Berdasarkan Tabel 4 diperoleh nilai rata-rata kesesuaian berada pada rentang nilai $80-100$ yaitu $88,07 \%$, mendekati $100 \%$ sehingga dapat disimpulkan secara keseluruhan bahwa atribut-atribut tersebut masuk dalam kategori "sesuai", artinya harapan masyarakat penerima layanansudah terpenuhi dengan baik.

Jika dilihat dari masing-masing indikator pelayanan, maka indikator yang dapat dikategorikan sudah sesuai dengan harapan masyarakat adalah: (1) Pemahaman tentang kemudahan prosedur pelayananPDAM Bandarmasih; Tanggungjawab petugas dalam memberikan pelayanan; (3) Keadilan untuk mendapatkan pelayanan; (4) Kewajaran biaya untuk mendapatkan pelayanan; dan, (5) Ketepatan pelaksanaan terhadap jadual waktu pelayanan.

Sedangkan indikator yang masih berada di bawah rata-rata tingkat kesesuaian adalah: (1) Pemahaman tentang kemudahan prosedur pelayanan PDAM Bandarmasih; (2) Kejelasan dan kepastian petugas yang melayani; (3) Kedisiplinan petugas dalam memberikan pelayanan; (4) Kemampuan petugas dalam memberikan pelayanan; (5) Kecepatan pelayanan, (6) Kesopanan dan keramahan petugas dalam memberikan pelayanan; (7) Kesesuaian antara biaya yang dibayarkan dengan biaya yang ditetapkan; (8) Kenyamanan di lingkungan unit pelayanan;dan, Keamanan pelayanan.

\section{Analisis Diagram Kartesius (IPA/Importance-Performance Analysis) terhadap Indikator-indikator Pelayanan}

Berdasarkan hasil perhitungan tingkat kesesuaian antara tingkat kinerja dengan tingkat kepentingan dan indikator kualitas pelayanan PDAM Bandarmasih seperti pada tabel di atas maka dapat peroleh gambar yang menunjukkan posisi dari setiap sub indikator pada kuadran tertentu, dapat dilihat pada Gambar berikut: 


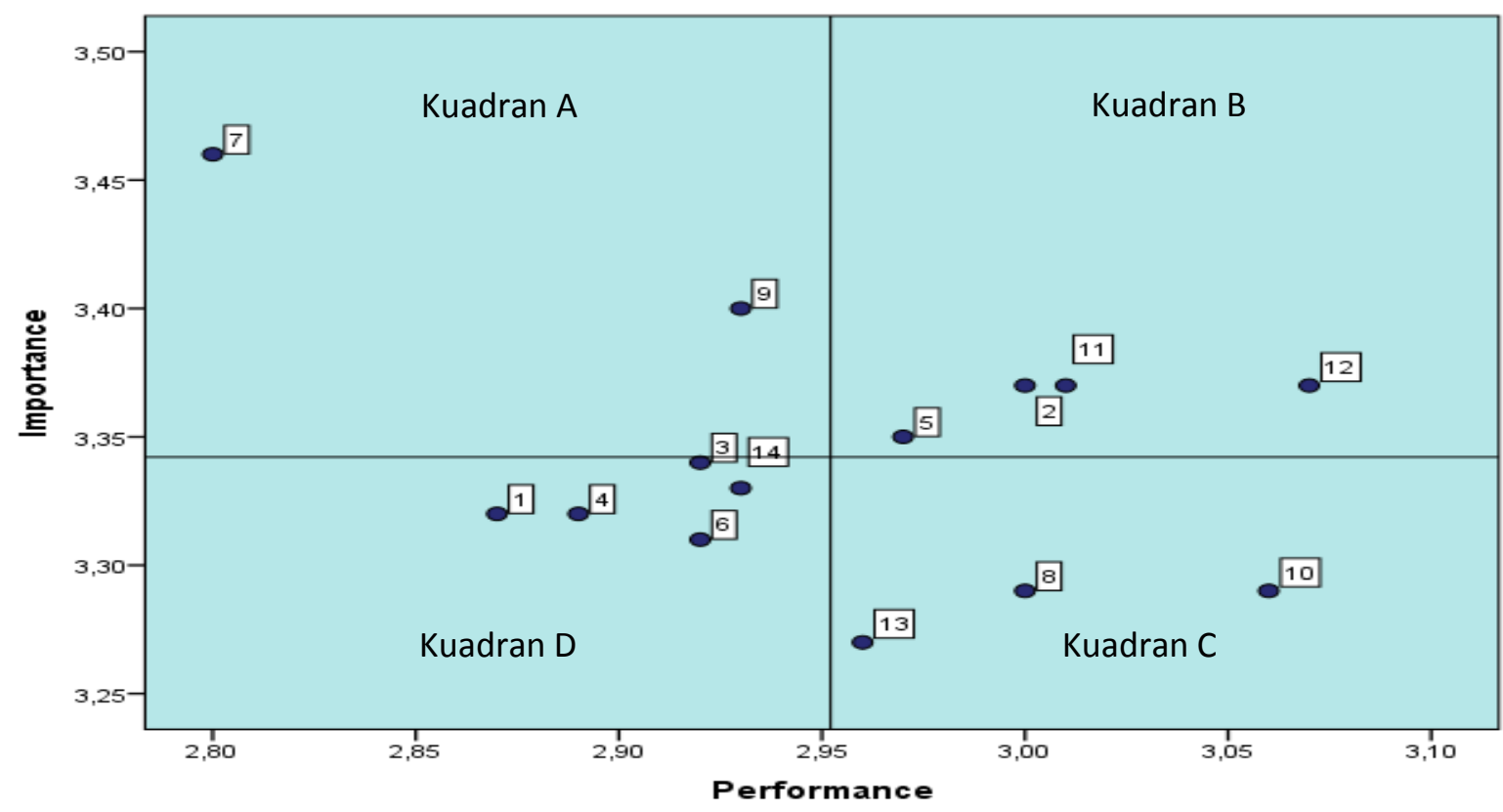

Gambar 1. Diagram Kartesius Pelayanan PDAM Bandarmasih

Berdasarkan diagram Kartesius, dapat digambarkan bahwa terdapat 4 kuadran yaitu kuadran A, B, C, dan D. Pada kuadran A terdapat sub indikatorindikator yang berkinerja rendah, namun mempunyai tingkat kepentingan yang tinggi. Kuadran A menunjukkan faktor atau atribut yang dianggap mempengaruhi kepuasan pelanggan, termasuk unsur-unsur jasa yang dianggap penting, namun manajemen belum melaksanakannya sesuai dengan keinginan pelanggan sehingga mengecewakan/tidak puas. Tingkat kepentingan yang tinggi mencerminkan bahwa para pelanggan PDAM Bandarmasih mempunyai harapan yang tinggi terhadap indikator-indkator tersebut. Jadi indikator-indikator yang berada pada kuadran ini seharusnya mendapat prioritas utama oleh pihak PDAM Bandarmasih untuk dilakukan perbaikan program. Indikator-indikator yang berada pada kuadran A pada hasil penelitian ini adalah: (1) Kecepatan pelayanan, dan (2) Kesopanan dan keramahan petugas dalam memberikan pelayanan.

Kuadran B menunjukkan unsur jasa pokok yang telah berhasil dilaksanakan oleh PDAM Bandarmasih. Dianggap sangat penting dan sangat memuaskan. Sub indikator-indikator yang berada pada kuadran ini adalah sub indikator yang memiliki harapan tinggi dari pelanggan dan kinerja yang tinggi dari pihak PDAM Bandarmasih. Pihak perusahaan perlu mempertahankan kinerjanya karena dengan begitu citra perusahaan dalam pelayanan kepada pelangga akan baik. Indikator-indikator yang berada pada kuadran B pada hasil penelitian ini adalah: (1) Pemahaman tentang kemudahan prosedur pelayanan PDAM Bandarmasih; (2) Tanggungjawab petugas dalam memberikan pelayanan; (3) Kesesuaian antara biaya yang dibayarkan dengan biaya yang ditetapkan; (4) Ketepatan pelaksanaan terhadap jadual waktu pelayanan.

Kuadran C menunjukkan faktor yang mempengaruhi pelanggan kurang penting, akan tetapi pelaksanaannya berlebihan. Dianggap kurang penting tetapi sangat memusakan. Pada kuadran ini terdapat beberapa sub indikator penilaian dengan tingkat kepentingan dan tingkat kinerja yang rendah. Walaupun sub indikator yang terdapat dalam kuadran ini dianggap tidak terlalu penting oleh pelanggan, tetapi hendaknya perusahaan selalu meningkatkan kinerjanya karena tingkat kepentingan masyarakat penerima manfaat program dapat meningkat tergantung kebutuhan. Beberapa sub 
indikator yang berada pada kuadran ini adalah: (1) Keadilan untuk mendapatkan pelayanan; (2) Kewajaran biaya untuk mendapatkan pelayanan; (3) Kenyamanan di lingkungan unit pelayanan.

Kuadran D menunjukkan beberapa faktor yang kurang penting pengaruhnya bagi pelanggan. Pelaksanaannya oleh perusahaan biasa-biasa saja. Dianggap kurang penting dan kurang memuaskan. Kuadran ini memuat sub indikator yang dirasa kurang penting oleh pelanggan, dan dari pihak perusahaan faktor ini juga tidak diprioritaskan pelaksanaannya. Pihak perusahaan tidak terlalu menjadikan sub indikator penilaian pada kuadran ini menjadi prioritas karena hanya akan menyebabkan terjadinya pemborosan biaya dan dapat dialokasikan untuk sub indikator yang berada pada kuandran lain. Indikator-indikator yang berada pada kuadran ini adalah: (1) Pemahaman tentang kemudahan prosedur pelayanan PDAM Bandarmasih; (2) Kejelasan dan kepastian petugas yang melayani; (3) Kedisiplinan petugas dalam memberikan pelayanan; (4) Kemampuan petugas dalam memberikan pelayanan; dan,

Keamanan pelayanan.

\section{PENUTUP}

\section{Simpulan}

Berdasarkan hasil penelitian, dapat diperoleh kesimpulan sebagai berikut:

1. Tingkat Kepuasan Masyarakat PDAM Bandarmasih di Banjarmasin terhadap pelayanan yang telah dilakukan PDAM Bandarmasih pada mutu pelayanan berdasarkan tingkat kinerja dan kepentingan masyarakat memiliki kinerja pelayanan yang baik (kategori B). Tingkat rata-rata kesesuaian antara tingkat kinerja dan tingkat kepentingan yang diperoleh dari hasil penelitian sebesar 88,07 mendekati $100 \%$ sehingga dapat disimpulkan secara keseluruhan bahwa pelaksanaan kinerja dengan tingkat kepentingan masuk dalam kategori "sesuai", artinya harapan masyarakat penerima layanan sudah terpenuhi dengan baik.

2. Pemetaaan indikator-indikator kualitas pelayanan Publik pada PDAM Bandarmasih di Banjarmasin dilakukan dengan importancePerformance Analysis diperoleh, indikator yang menjadi prioritas dalam pelayanan adalah:

Kecepatan pelayanan, (2) Kesopanan dan keramahan petugas dalam memberikan pelayanan. Indikator yang perlu dipertahankan kinerjanya adalah: (1) Pemahaman tentang kemudahan prosedur pelayanan; (2)Tanggungjawab petugas dalam memberikan pelayanan; (3) Kesesuaian antara biaya yang dibayarkan dengan biaya yang ditetapkan; dan, (4) Ketepatan pelaksanaan terhadap jadual waktu pelayanan.

\section{Rekomendasi}

PDAM Bandarmasih hendaknya lebih meningkatkan lagi mutu pelayanannya, karena dari hasil penelitian masih terdapat kesenjangan antara kinerja dengan tingkat harapan masyarakat, walaupun angka kesenjangan tersebut realatif kecil $(88,07)$ dan masih dalam kategori sesuai. Indikator-indiktor kualitas pelayanan publik bisa menjadi acuan dan pertimbangan bagi manajemen dalam upaya peningkatan kualitas layanan tersebut.

\section{DAFTAR PUSTAKA}

Batinggi, Ahmad, 1999. Manajerial Pelayanan Umum, Universitas Terbuka, Jakarta.

Denhardt, Janet V. and Denhardt, Robert B.2003,The New Public Service: Serving, not Steering, New York, M.E. Sharpe, Inc.

Fandy Tjiptono, 2014, Strategi Pemasaran, Edisi 4, Penerbit Andi, Yogyakarta. 
Gaspersz, V. 1997. Manajemen Kualitas:

Penerapan Konsep Vincent dalam Manajemen Bisnis Total, Gramedia Pustaka Utama, Jakarta.

Gasperz, Vincent, 1997. Manajemen Kualitas dalam Industri Jasa, PT Gramedia Pustaka, Jakarta.

Gerson, Richard F., 2002, Mengukur Kepuasan Pelanggan, Terjemahan, PPM, Jakarta.

Hardiyansyah. 2011. Kualitas Pelayanan Publik. Yogyakarta : Gava Media.

Hoffman, K. Douglas \& Bateson, John, E.C. 1997. Service Marketing, Concept, Strategies. South Western.

Kepmen PAN No. 25/M.PAN/2/2004. tentang Pedoman Umum Penyusunan Indeks Kepuasan Masyarakat Unit Pelayanan Instansi Pemerintah.

Kitcharoen, Krisana. 2004. The Importance-Performance Analysis of Service Quality and Administrative Departments of Private Universities in Thailand. ABAC Journal Vol. 24 No. 3 (September-December, 2004 pp. 20-46).

Lupiyoadi, Rambat et. Al, 2006, Manajemen Pemasaran Jasa, Edisi 2, Jakarta, Salemba Empat.

Moenir, H.A.S. 2006, Manajemen Pelayanan Umum Di Indonesia, Jakarta, Bumi Aksara.

Mowen, J.C, (1995), "Custumer Behaviour", Printice Hall Inc, New Jersey.
Mote, Frederik. 2008. Analisis Indeks Kepuasan Masyarakat (IKM) Terhadap Pelayanan Publik Di Puskesmas Ngesrep Semarang. Semarang, Universitas Diponegoro.

Nejati, Mehran dkk. (2007). 'Using SERVQUAL to Measure Employee Satisfaction: An Iranian Case Study', Proceeding of the 13th Asia Pacific Management Conference, Melbourne, Australia, Hal. 371 375.

PSP3 IPB. 2011. Laporan AkhirKajian Evaluasi Program Sanitasi Berbasis Masyarakat Wilayah Desa Ciherang dan Desa Caringin Kabupaten Bogor. Bogor.

Sinambela, Reformasi Pelayanan Publik, Airlangga, Jakarta, 2006 hal 5.

Sugiyono, 2012, Metode Penelitian Bisnis, Penerbit Alfabeta, Bandung.

Tambunan, Tuks, 2003, Perkembangan UKM dalam Era AFTA: Peluang, Tantangan, Permasalahan, dan Alternatif Solusinya, Paper Diskusi pada Yayasan Indonesia Forum.

Warella, Y. 1997, Administrasi Negara dan Kualitas Pelayanan Publik Pidato Pengukuhan jabatan Guru Besar Madya ilmu Administrasi Negara. Semarang, Universitas Diponegoro.

Zaithamal, V.A., Berry L.L. danParasuraman A. 2002. Delivery Quality Service.

Balancing Customer Perception and Expectation.New York: McGraw Hill. 